\title{
Influência do exercício físico agudo na expressão muscular de miR-206 em prole de camundongos com obesidade induzida por dieta hiperlipídica.
}

\section{Thomaz Guadagnini Ramalheira*, Thaís de Fante, Adriana Souza Torsoni.}

\section{Resumo}

Nos últimos anos, é possível observar um grande aumento na incidência de obesidade pelo mundo. Com isso, vários estudos surgem com o objetivo de avaliar diferentes mecanismos que possam estar relacionados com o avanço e surgimento desse distúrbio, dentre eles os mecanismos epigenéticos. Dessa forma, é de extrema importância conhecer a relação entre o exercício físico, muito utilizado no tratamento e prevenção da obesidade, e a modulação epigenética de microRNAs em prole de camundongos expostos à dieta hiperlipídica durante períodos críticos do desenvolvimento.

\section{Palavras-chave:}

Programação metabólica, exercício físico, microRNAs.

\section{Introdução}

O estilo de vida sedentário, associado à ingestão de uma dieta desequilibrada com predominância de gorduras pode acarretar no quadro de obesidade, visto como uma crescente em todo o mundo ${ }^{1}$. Diferentes alterações decorrentes dessa condição, tais como resistência a insulina e esteatose hepática ${ }^{2}$, podem ser em parte decorrentes de modulação epigenética que ocorre no metabolismo lipídico. Dentre os mecanismos epigenéticos, os microRNAs têm sido estudados devido ao seu importante papel na modulação da expressão gênica. Esses pequenos RNAs não codificantes ${ }^{3}$ podem, por exemplo, contribuir em alterações na expressão de diversos genes, podendo ter sua expressão alterada por uma mudança metabólica que provêm de períodos críticos do desenvolvimento ${ }^{4}$. Dessa forma, o presente estudo avaliou por RT-qPCR os microRNAs e seus alvos de interesse no músculo esquelético (quadríceps) da prole de camundongos fêmeas controles ou que consumiram dieta hiperlipídica durante a gestação e lactação. Após atingir a idade adulta, as proles foram divididas em grupos sedentários e treinados, afim de avaliar o efeito do exercício físico agudo na modulação dos microRNAs de interesse.

\section{Resultados e Discussão}

O peso das proles do grupo de mães que consumiram dieta HFD manteve-se sempre acima do grupo até o final do período experimental (Figura 1).

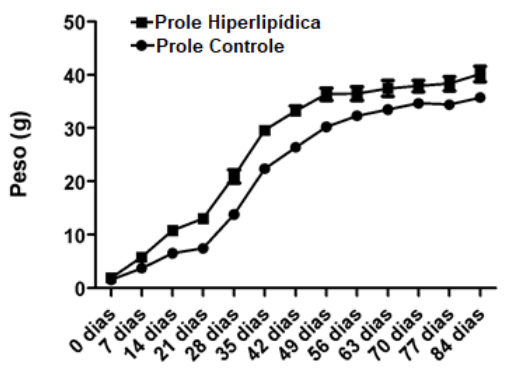

Figura 1. Peso das proles durante o período experimental. $\mathrm{N}=$ 10 por grupo.

Após análise por RT-PCR dos alvos de interesse, é possível observar na Figura 2 que em PTP1b e em PPARG o exercício físico consegue reverter os o quadro de programação metabólica nas proles de mães HFD. Já em HIF1a foi encontrada uma tendência, porém não houve diferença entre os grupos.
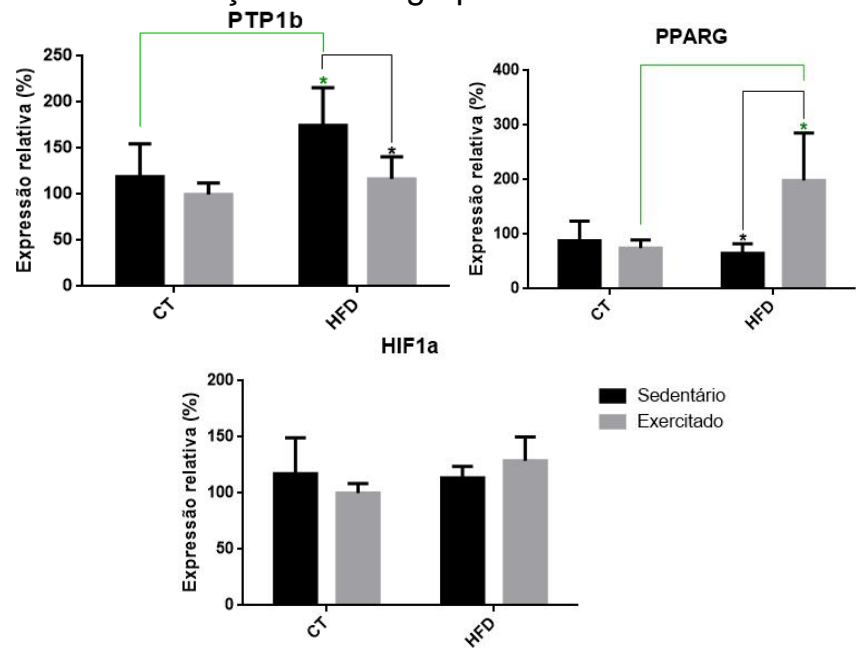

Figura 2. Expressão relativa do gene PTP1b, Pparg e HIF1a nos grupos estudados. $\mathrm{N}=5$ por grupo.

$\mathrm{Na}$ análise do microRNA-206 não houve diferença estatística entre os grupos (Figura 3).

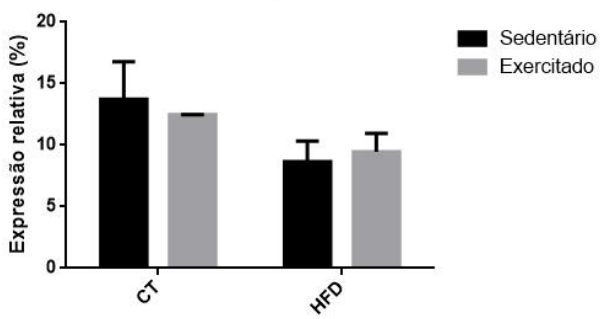

Figura 3. Expressão relativa do microRNA-206. $\mathrm{N}=5$ por grupo.

\section{Conclusões}

Os resultados do projeto sugerem que o estímulo agudo de exercício físico consegue reverter parcialmente as consequências da programação metabólica no músculo esquelético de proles de mães obesas.

${ }^{1}$ GAKIDOU, E. et al. Lancet 2014, v. 384, p. 766-781

2 MELDRUM, D. et al. Fertility and Sterility 2017, v. 107, n. 4, p. 833-839.

${ }^{3}$ KIM, V. Nature Reviews 2005, v. 6, p. 376-385.

${ }^{4}$ SIMINO, L. A. P. et al. Nutrition \& Metabolism 2017, 14:16 